\title{
Approaches for tsunami risk assessment and application to the city of Cádiz, Spain
}

\author{
R. Jelínek · E. Krausmann · M. Genzález · J. A. Álvarez-Gémez · \\ J. Birkmann · T. Welle
}

\begin{abstract}
Tsunamis can represent a significant risk to the population and cause huge economic damage in many costal regions. In order to be able to identify risk hot spots and implement targeted risk reduction measures, decision makers need to have a clear picture of the risk situation in their countries or regions. This work reviews existing approaches for tsunami risk assessment and recommends a five-step process for assessing tsunami risk. As a case study, a qualitative risk assessment for a worst-case tsunami scenario was carried out to understand the tsunami risk to the population in Cádiz. Moreover, a sensitivity analysis of the tsunami hazard input parameters was performed as a strong influence of the variability of the input parameters on the resultant tsunami hazard and risk zonation maps was observed. The study shows that regardless of the assumptions made a non-negligible tsunami risk to Cádiz exists.
\end{abstract}

Keywerds Tsunami · Risk assessment · Hazard · Vulnerability

\section{Intreduction}

In recent years, there has been a shift from hazard-oriented to risk-oriented approaches in natural hazard science. This shift was made necessary to better support the needs of

R. Jelínek ( $\square) \cdot$ E. Krausmann

European Commission, Joint Research Centre, Instute for the Protection and Security

of the Citizen, Via E. Fermi 2749, 21027 Ispra, VA, Italy

e-mail: robert.jelinek@jrc.ec.europa.eu

M. González

Ocean and Coastal Research Group, Instituto de Hidráulica Ambiental 'IH Cantabria', Universidad de Cantabria, E.T.S.I. Caminos Canales y Puertos, Avda de los Castros s/n, 39005 Santander, Spain

\section{J. A. Álvarez-Gómez}

Instituto Geográfico Nacional, C/General Ibáñez Ibero, n•3, 28003 Madrid, Spain

J. Birkmann · T. Welle

Institute for Environment and Human Security, United Nations University, Bonn, Gennany 
civil-protection authorities, land-use planners, insurance companies, etc., which require an updated picture of possible risk situations. As a consequence, a variety of approaches have been developed for assessing the risk of different natural hazards, notably for earthquakes, landslides or floods.

The situation regarding tsunami risk is different. A majority of tsunami studies that are available in the literature are focusing on tsunami hazard assessment. Relevant work in this area is describe for example in Rascon and Villarreal 1975; Nakamura 1978; Cox 1984; Damaskinidou-Georgiadou et al. 1987; Qinghai and Adams 1988; Symões et al. 1992; Synolakis et al. 1998; Zahibo and Pelinovsky 2001; Hébert et al. 2001; Legg et al. 2003; CSSC 2005; Kulikov et al. 2005. However, there is a lack of well-defined methodologies for the assessment of tsunami risk, and consequently, the availability of tsunami risk maps for decision making is very limited. In addition, the development of tsunami risk maps is a complex task. The main difficulty lies in the collection of the input data for analysis, which is insufficient for the majority of coastal regions as strong tsunamis are low probability events.

Recent tsunami events with severe consequences such as the Indian Ocean tsunami on 26 December 2004, initiated a number of activities related to this issue. Many countries with tsunami-prone coastal areas as well as the research community have launched dedicated programmes to mitigate tsunami risk. In response to the Indian Ocean tsunami, the European Commission has funded several tsunami-related research projects, such as TRANSFER (Tsunami Risk and Strategies for the European Region 2010), SAFER (Seismic Early Waming for Europe 2010), NEAREST (Integrated Observations from Near Shore Sources of Tsunamis: Toward an Early Warning System 2010), SEAHELLARC (Seismic Risk Assessment and Mitigation Scenarios in the Western Hellenic Arc 2010) or SCHEMA (Scenarios for Hazard-Induced Emergencies Management 2010).

Within the frame of the TRANSFER project, a need was recognised for the preparation of a document to guide the assessment of tsunami risk. In support of this, the Joint Research Centre reviewed the existing approaches to tsunami risk assessment with the aim to clarify the process of tsunami risk assessment and to prepare guidance (Jelínek and Krausmann 2008). This study provides a brief summary of various reviewed methods for tsunami risk assessment, which was updated with information that has become available since the publication of the original report. Particular emphasis is placed on the evaluation of the differences and similarities between the reviewed approaches. The process of a qualitative tsunami risk assessment is illustrated in detail using the city of Cádiz, Spain, as case-study area.

\section{Review of tsunami risk assessment appreaches}

\subsection{Definitions}

The definition of risk varies amongst different sectors. The generic approach described in the International Standard ISO 31000:2009 characterises risk by reference to potential events and consequences or a combination of these. In natural hazard science, the definition of risk as a product of hazard and vulnerability has gained international acceptance. This general definition has many variations depending on the purpose of analysis and the level of detail needed.

The estimation of risk can be carried out in a quantitative or qualitative way or as a combination of both. The selection of the type of analysis depends on the availability, 
quality and reliability of the required data and the purpose of the analysis. In practice, qualitative analysis is often used first to obtain a general indication of the level of risk or to perform an analysis for a large area with a low resolution (e.g. national or regional). Quantitative analysis can be used at a later stage to obtain more specific information for a small area with a high resolution (local). According to the Australian Geomechanics Society (2000), whenever possible, the risk estimate should be based on a quantitative analysis, even though the results may be summarised in a qualitative terminology. This gives a value of risk that can later be used in risk evaluation and treatment.

The most common results of a quantitative risk assessment (QRA) are individual risk and societal risk. Individual risk is presented as contour lines on a topographic map with frequencies of e.g. $10^{-4}-10^{-8}$ per year (CPR 1999). In a GIS environment, the results can be presented in a thematic risk map showing e.g. the annual probability of loss (people or damage to assets) in each grid cell. Societal risk is plotted in the form of frequencynumber curves (F-N curves). If data availability is not sufficient to carry out a QRA, a qualitative or semi-quantitative assessment relying on expert judgment is applied. The output of a qualitative risk assessment can be presented in the form of a risk matrix showing for example the relationship between the tsunami hazard and its potential consequences. A risk marix can be further translated into a thematic risk map in a GIS environment. Relative terms such as low, moderate and high are used to express the results. In semi-quantitative analysis, qualitative scales are assigned numerical values.

Depending on the purpose of the analysis, risk is calculated in terms of casualties (fatalities, injuries) and economic losses (direct or indirect e.g. due to business interruption). In most studies, it is limited to people loss or direct economic losses.

Various approaches have been proposed by different authors for tsunami risk assessment. In the following section, a summary of the reviewed approaches is presented using their original terminology. In this context, the term deterministic is synonymous with the term scenario-based, where the hazard and risk of a (credible) worst-case scenario are estimated without considering the likelihood or probability of occurrence of the scenario. The worst credible tsunami case is usually derive from historical tsunami data in the study zone or from the source characteristics combined with seismic data. This event is propagated to the study area using numerical models taking into account the highest tidal level in the zone. In the probabilistic assessment approach, all or the most relevant scenarios with their associated occurrence probabilities are used to estimate the hazard and risk. The probabilistic empirical analysis, generally called 'statistical analysis', is carried out for locations where historical records on tsunami run-up and amplitude data are available. A priori knowledge of source type is not needed to calculate the probabilities. In contrast, probabilistic computational-based methods rely on the lenowledge of source parameters, recurrence rates and their uncertainties. The advantage of computational methods compared to empirical ones is that they can be applied in regions with few historical records and can include parameter sensitivity estimates in the analysis.

\subsection{National approaches}

In the Pacific, where tsunamis have caused significant losses to coastal communities, this hazard has been studied extensively. Lee (1979) pointed out that the problem of tsunami risk analysis in the majority of locations is complicated by a lack of adequate historical tsunami records, such as the water level or nun-up. Therefore, a staightforward statistical approach for estimating the probability of a selected physical variable (or set of variables) is not possible to use for such locations. Alternatively, a so-called synthetic approach is 
applied for locations where the required historical data are not available but can be obtained by the numerical modelling of tsunami behaviour.

Pararas-Carayannis (1988) proposes general guidelines and a methodology for the evaluation of tsunami risk. The tsunami risk is considered in terms of frequency of occurrence, severity of impact, design adequacy of important costal stuctures and preparedness and planning for hazard mitigation. A similar approach for tsunami risk assessment is used in Curtis and Pelinovski (1999). Tsunami risk is expressed as a product of the probable frequency of tsunami occurrence and the number of people or facilities exposed. The risk significantly depends on distance to the source, the presence of an effective waming and evacuation system, as well as on education and raining.

The methodology for tsunami risk assessment in Australia and its Island Territories was developed based on earthquake and storm surge studies (Rym and Davidson 1999). The tsunami risk is a product of hazard and vulnerability. Hazard is assessed in quantitative terms considering tsunami magnitude, run-up height, wave height, damage observed from historical tsunamis, the distance of the coastline to near-field tsunamigenic sources and potential tsunami inundation in the future. Vulnerability is defined in qualitative terms for the built and natural environment. Once the risk components have been estimated, the resultant tsunami risk map is presented as a zonation map of five zones.

Tsunami risk and vulnerability analyses from the perspective of human response to waming, performed for selected coastal areas in Indonesia, are presented in Post et al. (2009). A variety of different factors, such as hazard assessment, time of tsunami arrival, receiving of technical and natural waming signs, reaction and evacuation time of population, are considere to identify hotspot areas and in particular weak response capabilities and evacuation times to expected tsunami arrivals.

A variety of tsunami risk-assessment methods have been developed in Greece. A semiquantitative approach to tsunami risk management proposed by Papadopoulos and Dermentzopoulos (1998) for the city of Heraklion considers risk as a product of the tsunami hazard (HA), the vulnerability of the socio-teclinological system (VU) and the economical value expose to the hazard (VA). Other examples of tsunami vulnerability assessment from Greece can be found in Papathoma and Dominey-Howes (2003) and Papathoma et al. (2003). The authors demons rate the importance of the vulnerability component in tsunami risk assessment as a very dynamic factor depending on a number of parameters relating to the built environment, sociological, economic, environmental and physical data. However, the tsunami source and offshore bathymery are neglected in this approach.

After the Indian Ocean tsunami in 2004 also counries where tsunamis do not represent a significant risk have started national programs on tsunami risk assessment. In the United Kingdom, the concept and principles of the Risk Assessment for Strategic Planning (RASP) methodology originally developed for fluvial and coastal flooding have also been applied to tsunami risk assessment. It is assumed that risk arising from more frequently occurring flood hazards can be assessed and compared with tsunamis (DEFRA 2005).

The approach proposed by Tinti et al. (2008) presents a tsunami risk assessment for the eastern coast of Sicily. The authors restricted their analysis to the people that live permanently or temporarily in the coastal zone. Tsunami risk in this approach is a function of the tsunami hazard base on numerical modelling and the vulnerability of the population based on socio-economic analysis. The probability of occurrence of a tsunami is based on the combination of statistical (seismicity) and deterministic (hydrodynamics) analysis in a so-called hybrid method (Tinti et al. 2005). The total tsunami risk is expressed in terms of the expected number of persons that are affected by a given tsunami for a given period of time. 
A probabilistic methodology to estimate the tsunami risk at national level has been developed for the New Zealand coastline (Berryman 2006). The tsunami risk is estimated for an individual in urban centres (refers here as risk to communities) or for those who live at low elevations close to the coast (i.e. individual risk) and for a nation as a whole (i.e. national risk). The results of the risk assessment are presented as risk curves showing the relation of various retum periods (from 50 to 2,500 years) to the wave heights at the shoreline, the costs of damage to buildings or the estimated numbers of fatalities and injuries. The results are used to estimate the annual risk of death to individuals (e.g. $10^{-2}-10^{-3}$ is widely regarded as intolerable event). An alternative to this probabilistic risk assessment approach is the qualitative determination of the consequences of a number of different tsunami scenarios.

A scenario-based tsunami risk assessment approach is proposed in Nadim and Glade's (2006) work to assess the tsunami risk for the West Coast of Thailand. The authors argue that this approach is well suited for the evaluation of tsunami risk where not enough data are available to establish the magnitude-frequency statistics for tsunamis. Similarly, the scenario-based approach is suited because the physical characteristics of the tsunami are known, i.e. the direction of the loading and the extent of the affected area by a potential tsunami scenario can be identified.

An effective way of managing tsunami risk is the 'multi-hazards risk' or 'all-hazards' approach. The multi-hazard risk approach considers the impact of all natural and teclinological hazards of concern on people, services, facilities and structures in a specific area, rather than focus on a single hazard or risk. Tsunami risk assessment is investigated as a part of the multi-risk city projects carried out by Geoscience Auscalia (Granger et al. 1999). The entire process of risk management involving the establishing of the context, identifying, analysing, evaluating, reating, monitoring and communicating the risk is outlined in the generic guide Australian/New Zealand Standard AS/NZS 4360 (2004). The report edited by Middelmann (2007) provides an overview of risk analyses of different natural hazards, which also includes tsunamis.

The information presented earlier is summarised in Table 1 where the selected approaches are classified according to their type and output of analysis.

\subsection{Recommendations for assessing tsunami risk}

A majority of the reviewed assessment methodologies share a similar stucture and include the following main steps: hazard identification and characterisation, assessment of consequences (exposure and vulnerability) and risk characterisation. The similarity lies in the origin of the reviewed tsunami risk assessment approaches, which are usually based on 'generic' methods for risk assessment or those used for estimating the risk of earthquakes, storm surge or floods. The main differences lie in the methods used for risk estimation and the presentation of the results. Some common outputs are in the form of thematic risk maps (e.g. tsunami risk zonation map, death rate distribution map, evacuation map, etc.), tables or F-N curves.

The results also indicate that tsunami risk assessment is generally performed using either a probabilistic or a deterministic approach. If sufficient and reliable data are available, then the probabilistic tsunami risk assessment should be applied rather than the deterministic approach. The probabilistic approach provides a more realistic picture of the risk to the investigated area, and it has a higher significance for the planning of effective countermeasures. Moreover, a quantitative risk figure can be more easily compared with 
Table 1 Summary of selected tsunami risk assessment approaches and their methodological background

\begin{tabular}{|c|c|c|}
\hline Source & Type of approach & Analysis process and output \\
\hline Lee (1979) & $\begin{array}{l}\text { Probabilistic approach in case of } \\
\text { sufficient data regarding bistorical } \\
\text { tsunamis (e.g. the maximum water } \\
\text { level, rum-up) } \\
\text { Synthetic approach as alternative, } \\
\text { based on tsunami sources, reliable } \\
\text { numerical models and reliable } \\
\text { probability of tsunamigenic source } \\
\text { parameters }\end{array}$ & $\begin{array}{l}\text { Synthetic approach } \\
\text { Characterisation of source parameters of } \\
\text { tsunami } \\
\text { Probability of occurrence of a } \\
\text { tsunamigenic event } \\
\text { Run-up modelling }\end{array}$ \\
\hline \multirow[t]{4}{*}{$\begin{array}{l}\text { Pararas-Carayannis } \\
\quad(1988)\end{array}$} & $\begin{array}{l}\text { Statistical approach, if historical } \\
\text { information is available }\end{array}$ & $\begin{array}{l}\text { Historical studies on local and distant } \\
\text { origin of tsunami, seismicity of region } \\
\text { for zonation of tsunami hazard }\end{array}$ \\
\hline & \multirow[t]{3}{*}{$\begin{array}{l}\text { Deterninistic approach using } \\
\text { hydraulic scale models or } \\
\text { numerical models, in the absence } \\
\text { of historical infonnation }\end{array}$} & $\begin{array}{l}\text { Tsunami hazar frequency (statistical } \\
\text { approach) if ata availability is good } \\
\text { Tsunami modelling studies as alternative } \\
\text { to the above using hydraulic scale } \\
\text { models or numerical modelling }\end{array}$ \\
\hline & & $\begin{array}{l}\text { Zonation of the tsunami hazard as } \\
\text { product of the historical studies on } \\
\text { tsunami frequency and of the } \\
\text { modelling studies }\end{array}$ \\
\hline & & $\begin{array}{l}\text { Risk in terms of frequency of } \\
\text { occurrence, severity of impact and } \\
\text { design adequacy of important coastal } \\
\text { structures and also preparedness and } \\
\text { planning for hazard mitigation }\end{array}$ \\
\hline \multirow[t]{5}{*}{$\begin{array}{l}\text { Curtis and Pelinovslie } \\
\text { (1999) }\end{array}$} & \multirow[t]{5}{*}{$\begin{array}{l}\text { Statistical, deterministic or hybrid } \\
\text { method is used depending on data } \\
\text { availability on historical tsunamis }\end{array}$} & $\begin{array}{l}\text { Historical studies on past tsunamis, } \\
\text { analysis of seismicity, detenninistic } \\
\text { analysis of possible tsunami scenarios }\end{array}$ \\
\hline & & $\begin{array}{l}\text { Probability of occurrence of an event } \\
\text { based on geological information, } \\
\text { bistorical and recorded data }\end{array}$ \\
\hline & & $\begin{array}{l}\text { Risk calculation depending on tsunami } \\
\text { source and the presence of an effective } \\
\text { waming and evacuation system }\end{array}$ \\
\hline & & $\begin{array}{l}\text { Risk components are the probable } \\
\text { frequency of occurrence and the } \\
\text { number of people (or facilities) } \\
\text { exposed }\end{array}$ \\
\hline & & Specific risk to person or structure \\
\hline \multirow[t]{3}{*}{$\begin{array}{l}\text { Rynn and Davidson } \\
\text { (1999), Granger } \\
\text { et al. (1999) }\end{array}$} & \multirow[t]{3}{*}{ Deternninistic approach } & $\begin{array}{l}\text { Risk }=\text { hazard } \times \text { vulnerability } \\
\text { Tsunami hazard map is prepared using } \\
\text { deterministic (real data) approach for } \\
\text { three zones: high, medium and low }\end{array}$ \\
\hline & & $\begin{array}{l}\text { Map of vulnerable areas in qualitative } \\
\text { terms as low, medium and bigh } \\
\text { vulnerabilities }\end{array}$ \\
\hline & & Tsunami zonation map ( 5 zones) \\
\hline
\end{tabular}


Table 1 continued

\begin{tabular}{|c|c|c|}
\hline Source & Type of approach & Analysis process and output \\
\hline $\begin{array}{l}\text { Papadopoulos and } \\
\text { Dermentzopoulos } \\
\text { (1998) }\end{array}$ & $\begin{array}{l}\text { Semi-quantative approach } \\
\text { that combines numerical } \\
\text { modelling with a probabilistic } \\
\text { approach }\end{array}$ & $\begin{array}{l}\text { Tsunami risk management-prevention and } \\
\text { mitigation measures map as the final product } \\
\text { of integration of the results from } 11 \text { thematic } \\
\text { maps. } \\
\mathbf{R}=\mathbf{H A} \times \text { VU } \times \text { VA }\end{array}$ \\
\hline $\begin{array}{l}\text { Papathoma and } \\
\text { Dominey-Howes } \\
\text { (2003), Papathoma } \\
\text { et al. (2003) }\end{array}$ & Hybrid approach & $\begin{array}{l}\text { Study on historical tsunamis to calculate the } \\
\text { probability (return periods) of tsunamis of } \\
\text { different intensities } \\
\text { Identification of the (extreme) inundation zone } \\
\text { based on the bighest recorded tsunami } \\
\text { Identification of factors that affect the } \\
\text { vulnerability of buildings and people } \\
\text { Calculation of the vulnerability for buildings } \\
\text { and people } \\
\text { Preparation of maps showing the human and } \\
\text { building vulnerability }\end{array}$ \\
\hline Berryman (206) & $\begin{array}{l}\text { Probabilistic approach that } \\
\text { considers all likely future } \\
\text { events, i.e. size, frequency } \\
\text { and effects of all sources }\end{array}$ & $\begin{array}{l}\text { Tsunami-generating sources i.e. the size and } \\
\text { frequency of all possible sources such as } \\
\text { earthquakes, landslides and volcanoes } \\
\text { Wave propagation through water using } \\
\text { numerical modelling } \\
\text { Flooding of the water across land (inundation) } \\
\text { Location and diswibution of assets at risk } \\
\text { (people, dwellings, other buildings) } \\
\text { How easily assets and people are damaged } \\
\text { (fragility) } \\
\text { Plots showing hazard and risk as a function of } \\
\text { return period for individual and national risk } \\
\text { Individual risk in tabular form }\end{array}$ \\
\hline $\begin{array}{l}\text { Nadim and Glade } \\
\quad(2006)\end{array}$ & $\begin{array}{l}\text { Scenario-based approach, } \\
\text { wbich considers several } \\
\text { scenarios of plausible } \\
\text { exweme, or tsunami- } \\
\text { generating earthquakes }\end{array}$ & $\begin{array}{l}\text { Define scenarios for tsunami-generating } \\
\text { earthquakes } \\
\text { Compute the tsunami inundation levels for the } \\
\text { scenario earthquake events } \\
\text { Estimate the tsunami risk for different scenarios } \\
\text { Compare the estimated risk with tolerable or } \\
\text { acceptable risk levels }\end{array}$ \\
\hline Tini et al. (2008) & $\begin{array}{l}\text { Scenario-based approach for a } \\
\text { small tsunami ( } 1 \mathrm{~m} \text { nu-up on } \\
\text { coast) and a large tsunami } \\
\text { (5 m run-up on coast) }\end{array}$ & $\begin{array}{l}\text { Hazard map created using numerical modelling } \\
\text { Vulnerability based on socio-economic analysis } \\
\text { of population } \\
\text { Impact map of number of people potentially } \\
\text { affected by selected tsunami scenario (for } \\
\text { summer and winter season) }\end{array}$ \\
\hline
\end{tabular}

other areas or risks. Table 2 summarises the applicability of each approach depending on data availability and scale.

The review showed that the terms 'risk assessment' and 'risk analysis' are sometimes interchanged. According to standard terminology, risk analysis refers to the process of determining the nature and the level of risk, while risk assessment also compares the 
Table 2 Recommended approaches for the estimation of tsunami risk

\begin{tabular}{|c|c|c|c|}
\hline Data availability & Scale of analysis & Approach & Outcome \\
\hline $\begin{array}{l}\text { Sufficient historical data } \\
\text { on past tsunamis (e.g. } \\
\text { historical tsunami } \\
\text { catalogue, magnitudo- } \\
\text { frequency data) }\end{array}$ & $\begin{array}{l}\text { Site-specific } \\
\text { Local } \\
\text { Regional }\end{array}$ & $\begin{array}{l}\text { Probabilistic approach } \\
\text { using bistorical } \\
\text { records on rm-up }\end{array}$ & $\begin{array}{l}\text { Quanitative assessment } \\
\text { Individual risk } \\
\text { Societal risk } \\
\text { Economic risk }\end{array}$ \\
\hline \multirow[t]{3}{*}{$\begin{array}{l}\text { No historical records on } \\
\text { past events }\end{array}$} & Regional & $\begin{array}{l}\text { Deterministic } \\
\text { approach using: }\end{array}$ & Qualitative assessment \\
\hline & National & $\begin{array}{l}\text { Models: numerical or } \\
\text { physical }\end{array}$ & Risk matrix \\
\hline & & $\begin{array}{l}\text { Selection of specific } \\
\text { elevation contour } \\
\text { lines based on local } \\
\text { conditions }\end{array}$ & $\begin{array}{l}\text { Semi-quantitative } \\
\text { assessment } \\
\text { Risk matrix }\end{array}$ \\
\hline
\end{tabular}

estimated risk level to acceptability criteria (risk evaluation). Therefore, we propose the following procedure for assessing tsunami risk:

1. Scope definition: the problem is defined, and the basic input parameters for the chosen assessment approach are established.

2. Hazard analysis: aims at determining the tsunami severity and its frequency.

3. Vulnerability analysis: identifies the elements at risk with respect to the potential tsunami and their vulnerability.

4. Risk estimation: combines information from steps 2 and 3 to determine either quantitatively or qualitatively the level of risk to a given risk receptor.

5. Risk evaluation: As a final step, the estimated risk is compared with risk acceptability criteria, if they exist, to determine whether the risk needs to be reduced by implementing targeted measures.

In order to illustrate the proposed framework for tsunami risk assessment, it was applied to the city of Cádiz for which a qualitative risk assessment was performed.

\section{Tsunami risk assessment for Cádiz, Spain}

The Bay of Cádiz is geographically located between longitudes $6^{\bullet}$ and $6^{\bullet} 25^{\prime} \mathrm{W}$ and latitudes $36^{\circ} 20^{\prime}$ and $36^{\circ} 40^{\prime} \mathbf{N}$, in the south-west of Iberian Peninsula (Fig. 1). It faces west to the Gulf of Cádiz and is landlocked around its south-western, southem and eastem margins by the mainland. This area is a natural protection zone with large tidal flats, tidal channels and several beaches.

The city of Cádiz is relatively small $\left(13.3 \mathbf{~} \mathbf{m}^{2}\right)$ and is divided into 112 districts. The average elevation of the city is about $36 \mathrm{~m}$, which makes its population highly vulnerable to a potential tsunami impact. The population density is high with approximately 9,500 inhabitants per $\mathbf{k} \mathbf{m}^{2}$. This number increases considerably during the summer months due to tourism. This coastal area was affected by tsunamis in the past. Damaskinidou-Georgiadou et al. (1987) indicated that significant tsunamis like the one riggered by the Great Lisbon Earthquake of 1 November 1755 can affect the coast with 


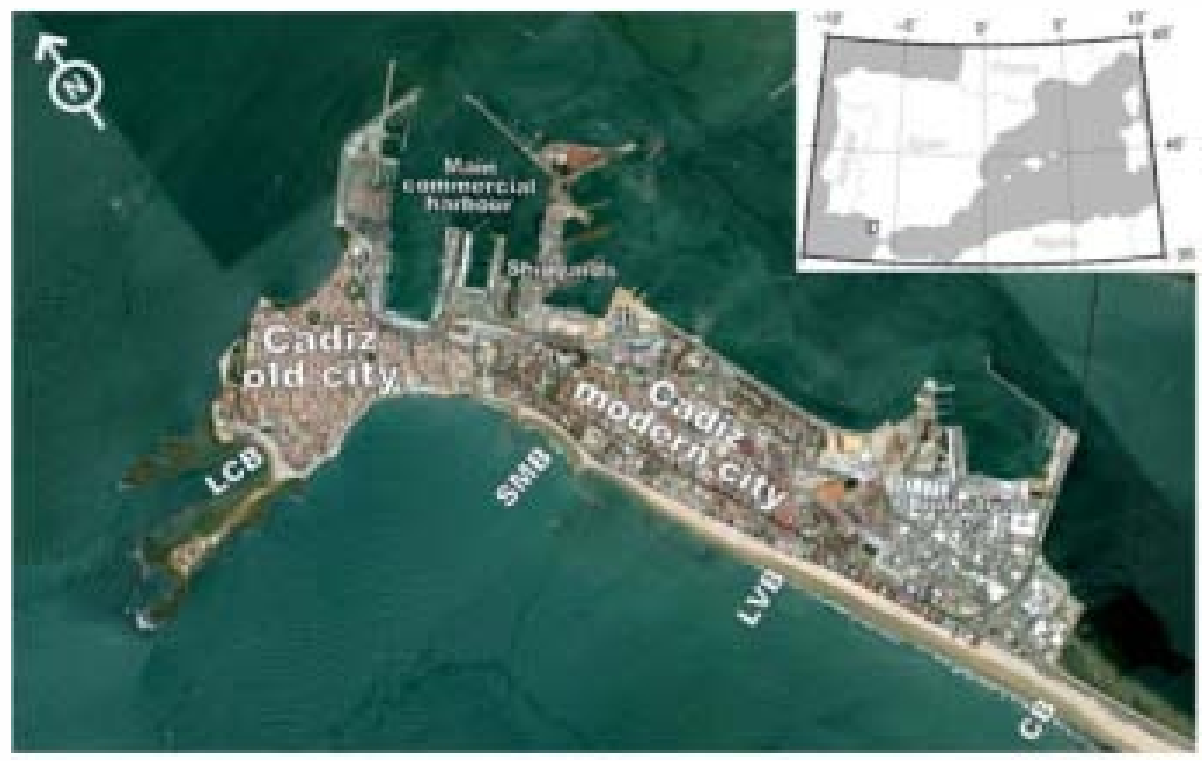

Fig. 1 Area of study, the city of Cádiz, situated to the south-west of the Iberian Peninsula in the Atlantic margin of southern Spain. LCB La Caleta beach, SMB Santa Maria beach, LVB La Victoria beach, $C B$ Cortadura beach

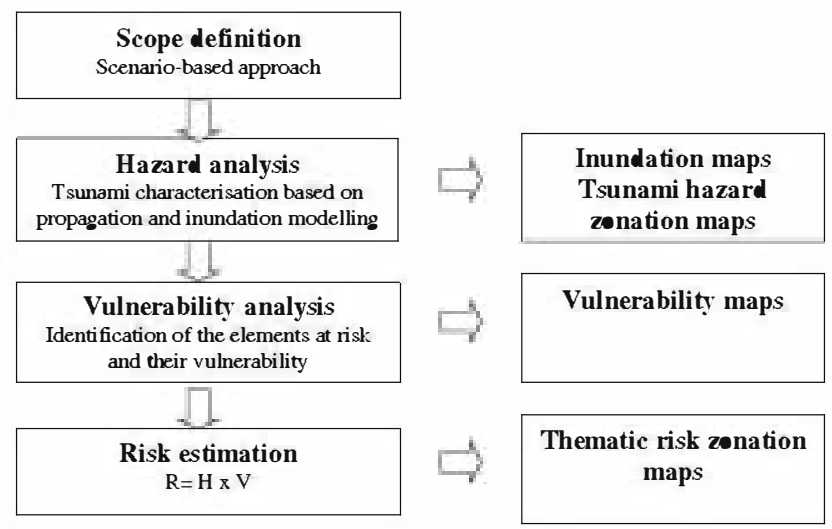

Fig. 2 Flowchart showing the tsunami risk assessment procedure and output for Cádiz

a retum period of approximately $250-400$ years. The risk assessment performed for Cádiz follows the framework for tsunami risk assessment outlined in the previous section. The flowchart in Fig. 2 provides an overview of the main analysis steps and their respective outcome. Due to the unavailability of risk acceptance criteria, the evaluation of the calculated risk was not performed. 


\subsection{Scope definition}

Since the availability of historical data on past tsunamis is limited for the case-study area, a scenario-based approach was used to calculate the tsunami risk. A so-called 'worst-case' scenario, which is a combination of the maximum credible earthquake that generates a tsunami propagated on the highest tidal level in the zone, was selected for this purpose. This scenario represents an aggregation of the inundation levels obtained for five maximum credible tsunami scenarios generated from each of five fault sources identified as relevant to Cádiz (Fig. 3). These faults form part of the Azores-Gibraltar fault zone and are the Gorringe Bank fault, the Horseshoe Fault, the Marques de Pombal Fault, the Portimão Bank Fault and the Cádiz Wedge Fault. For each source zone, a maximum credible earthquake was designed and the associate maximum credible tsunami identified. The distribution function of the tidal level was included in these scenarios.

Most damaging earthquakes and tsunamis that affected the coasts of Portugal, Morocco and Spain were probably generated in the SWIT (SW Iberian Transpressive Domain) zone, including the Cadiz mega-tsunami of 1 November 1755. In the present study, only the tsunamigenic areas in the SWIT region have been considered. This area of tectonic deformation is responsible for the offshore seismicity of south-western Iberia. The worst cases, as well as the fault races that we used for the Cadiz Bay area, are described in Lima et al. (2010), and their summary is presented in Table 3.

A more detailed description of the tsunami sources is provided in UC-IGN (2009) and UCA (2009). The tsunami risk was only estimated for the population distributed in 112 municipal districts of Cádiz. No other risk such as to property or environment was analysed. In the proposed case study, tsunami risk to the population is expressed as a product of hazard times vulnerability.

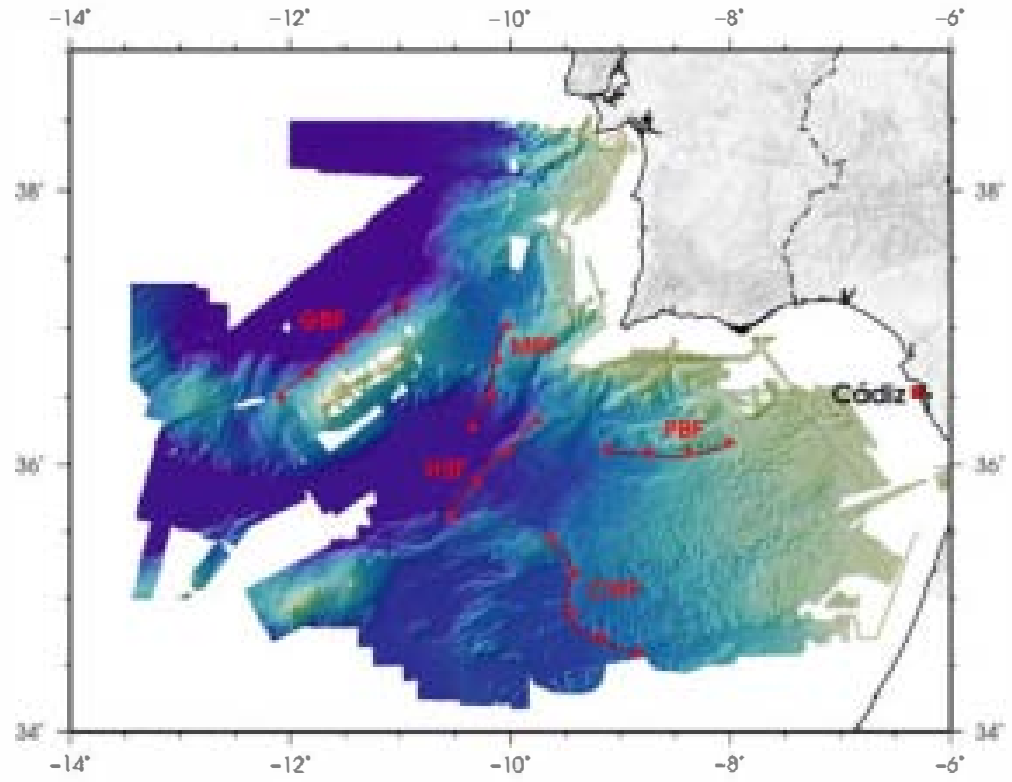

Fig. 3 Topo-bathymewic map showing the considered tsunamigenic seismic sources. CWF Cadiz wedge fault, GBF Gorringe bank fault, HSF horseshoe fault, MPF Marques de Pombal fault, PBF Portimao bank fault. Bathymeric data from Zitellini et al. (2009) 
Table 3 Characteristics of tsunami sources [from Lima et al. (2010)]

\begin{tabular}{|c|c|c|c|c|c|c|c|c|}
\hline Faults & Length $(\mathrm{km})$ & Width $(\mathrm{km})$ & $\begin{array}{l}\text { Max. } \\
\text { depth }(\mathrm{km})\end{array}$ & Slip (m) & Swike $\left({ }^{\bullet}\right)$ & Dip $\left(^{\bullet}\right)$ & Rake $\left(^{\bullet}\right)$ & $\mathrm{Mw}$ \\
\hline GBF & 137 & 60 & 25 & 8.3 & 233. & 25 & 90 & 8.1 \\
\hline HSF & 106 & 70 & 25 & 10.7 & 222.1 & 25 & 90 & 8.2 \\
\hline MPF & 86 & 7 & 25 & 8.0 & 200.0 & 25 & 90 & 8. \\
\hline PBF & 100 & 55 & 25 & 7.2 & 266.3 & 25 & 90 & 8. \\
\hline CWF & 133 & 200 & 12 & 11.1 & 346.3 & 6 & 90 & 8.6 \\
\hline
\end{tabular}

\subsection{Hazard analysis}

The hazard analysis focuses on both the characterisation of the tsunami severity and its frequency to create tsunami hazard or flooding maps. Since our study is based on a worstcase scenario, no frequency or occurrence probability was assigned to this 'artificial' event. The analysis of tsunami hazard was, therefore, limited to characterising the tsunami severity. This includes the identification of the relevant tsunamigenic sources and their parameters for wave propagation and inundation modelling. The wave elevation, water depth, current speed, Froude number and flow forces were provided in UC-IGN (2009) who used the C3 (Cantabria, COMCOT and Tsunami-Claw) numerical model to calculate these parameters. The $\mathrm{C} 3$ model is base on non-linear shallow water equations (labarrieta et al. 2010). Not all of the calculated tsunami parameters lend themselves easily for the production of tsunami hazard zonation maps. Therefore, key atwibutes that best represent the tsunami hazard for a specific type of risk analysis, scale or level of investigation need to be selected. Since our study is limited to population only, it was decided that the inundation maps for Cádiz would be described by the water depth and the current velocity. These are the most relevant factors that control the stability of people in flowing water. This approach was also used by Jonkman et al. (2008) who studied human instability in flowing water as a function of water depth-velocity products. In order to simplify the analysis, every district was approximated by one value of the depth-velocity product. The resulting inundation map for the worst-case scenario in Cádiz is presented in Fig. 4.

Tsunami hazard zonation maps illustrate in relative terms where a tsunami may occur. In order to prepare these maps, the water depth-velocity values in Fig. 4 had to be assigned accompanying hazard levels. Jonleman et al. (2008) indicate the critical depth-velocity products for being able to stand range from 0.6 to about $2 \mathrm{~m}^{2} / \mathrm{s}$. The first three depthvelocity categories are in accordance with the experimental data presented by these authors. However, due to the large data range in Fig. 4, depth-velocity values above $2 \mathrm{~m}^{2} / \mathrm{s}$ were split into two further sub-categories. Each depth-velocity category was then assigned a score from one to five with a relevant hazard level (Table 4). In order to consider the boundaries of the model output, minimum, maximum and average values of the depthvelocity product for every district were used to produce tsunami hazard zonation maps (Fig. 5).

The chart presented in Fig. 6 clearly shows the effect of three different input parameters used. For example, using the minimum level of the depth-velocity relation, 33 districts fall into the very low tsunami hazard category. Using maximum values, only 3 districts remain in this category. It is interesting to note that the highest number of districts is located in areas subject to very high hazard levels regardless of the chosen depth-velocity reference value. This is likely a consequence of the worst-case approach. 
Depth-velocity relation for the worst case scenario - Cadiz, Spain

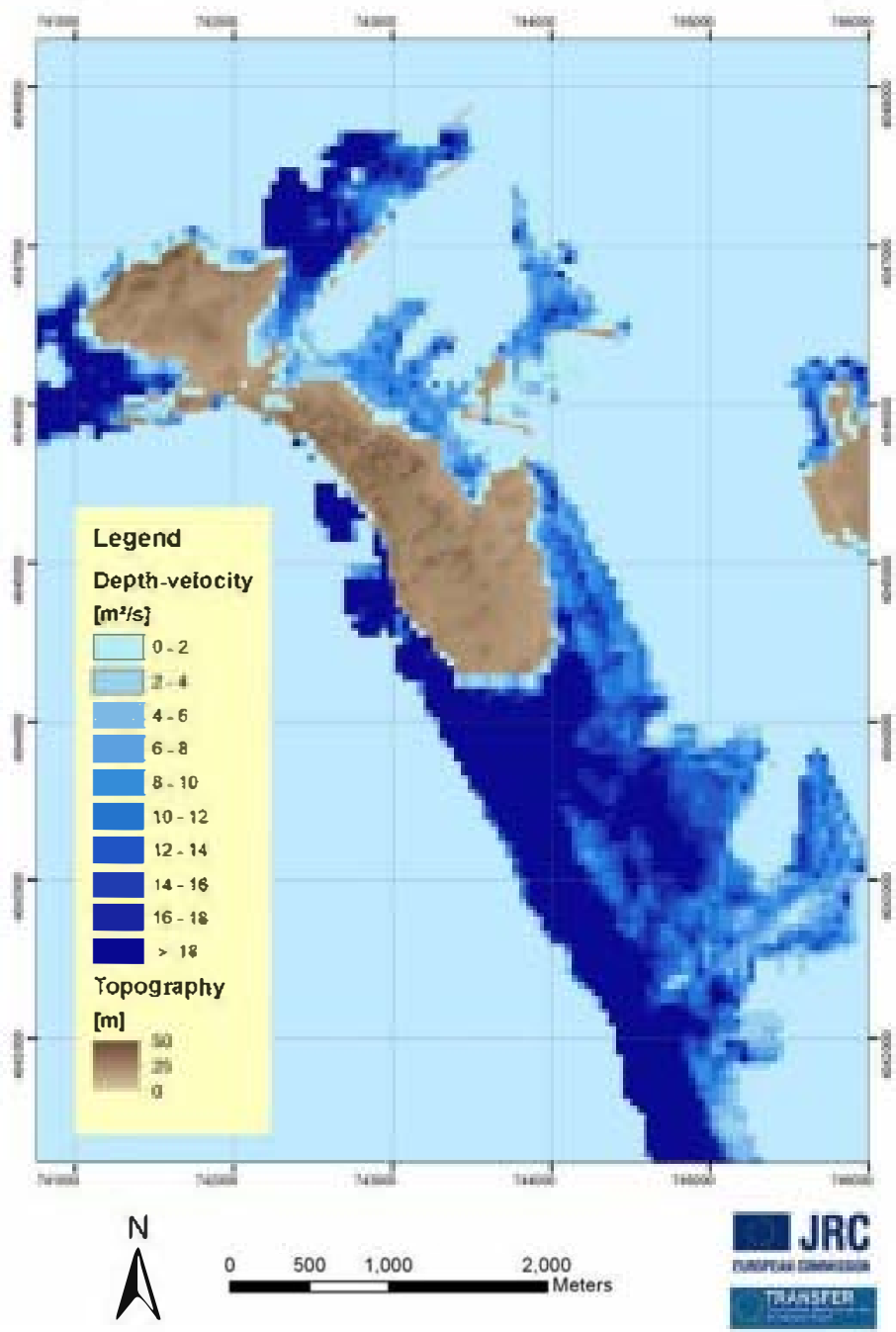

Fig. 4 Thematic map of the maximum water depth-velecity product for the worst-case scenarie

Table 4 Tsunami hazard level as a function of depth-velecity relation, modified from Jonkman et al. (205)

\begin{tabular}{|c|c|c|c|}
\hline Depth-velocity relation $\left(\mathrm{m}^{2} / \mathrm{s}\right)$ & Description & Assigned scere & Hazard level \\
\hline$<0.6$ & No danger & 1 & Very low (VL) \\
\hline e.6-1.35 & Danger for some & 2 & Low (L) \\
\hline $1.35-2.0$ & Danger for mest & 3 & Medium (M) \\
\hline $2.0-5.0$ & Danger for all & 4 & $\mathrm{High}(\mathrm{H})$ \\
\hline$>5$. & Very dangerous & 5 & Very high (VH) \\
\hline
\end{tabular}



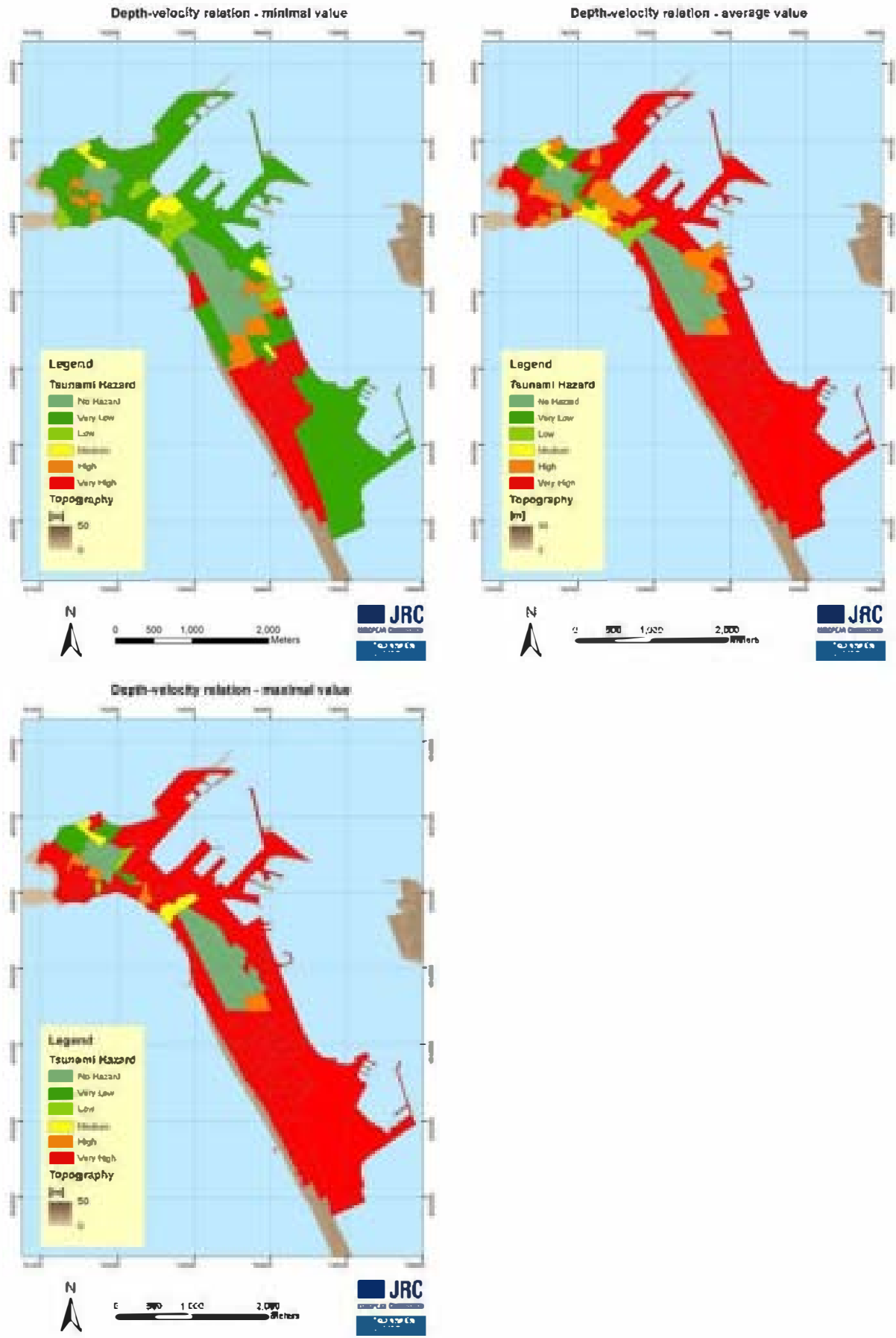

Fig. 5 Tsunami hazat zonation maps for minimum, average and maximum values of the water depthvelecity preduct 


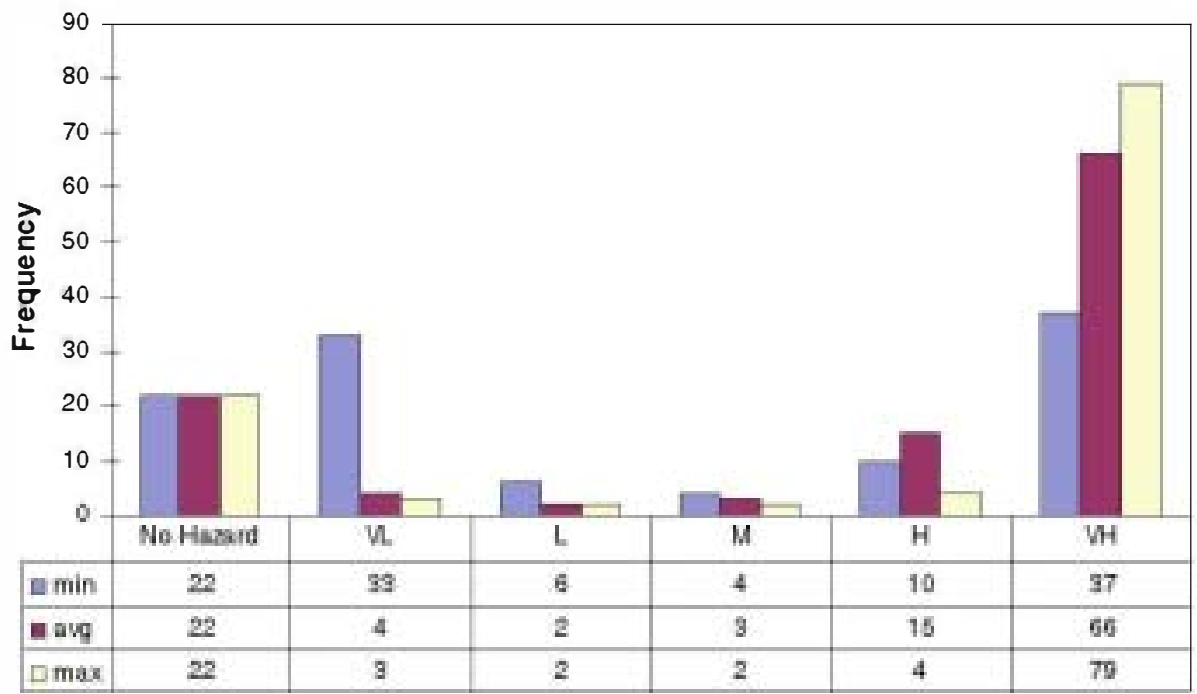

Fig. 6 Number of diswicts per hazard level for the minimum, average and maximum values of the water depth-velocity parameter

\subsection{Vulnerability analysis}

Vulnerability analysis includes the identification of the elements at risk due to their location with respect to the potential tsunami and the estimation of the likelihood of injury, loss, disruption of livelihood and other harm, as well as the capacity of persons or property to cope with and recover from the impact of the tsunami (Wisner et al. 2004). A detailed general discussion on vulnerability analysis is provided by Birlemann (2006).

The vulnerability in our study relates to the characteristics of the affected population and their ability to respond to the tsunami defined by the worst-case scenario. The vulnerability analysis carried out in this work is based on the parameter exposure, coping capacity and susceptibility, which ackowledges the fact that vulnerability is influence by intemal and external factors (see also Birlemann et al. 2010). Exposure to a hazard is an external factor, while susceptibility and coping capacity are internal ones, which indicate the 'conditions of the exposed element or community' and 'the means by which people or organisations use available resources and abilities to face adverse consequences', respectively (Thywissen 2006). Exposure was calculated based on the inundation data obtained by numerical modelling. The susceptibility was based on two indicators. The first indicator comprises the percentage of population younger than 6 and older than 65 years. These thresholds are based on the findings from studies in Sri Lanka and Indonesia that were carried out after the 2004 tsunami (Rofi and Doocy 2006). The second indicator corresponds to the combination of dependency ratio and gender ratio and states the percentage of total population that has to be supported by the male in working age. In order to characterise the coping capacity, the percentage of buildings with more than one level to which people could vertically evacuate, the number of people that has received school education for more than 6 years, the sum of children $<6$ years, illiterates and non-Spanishspeaking migrants were considered. The first two are positive coping factors, whereas the last ones describe a negative coping factor as it is assumed that this portion of the 


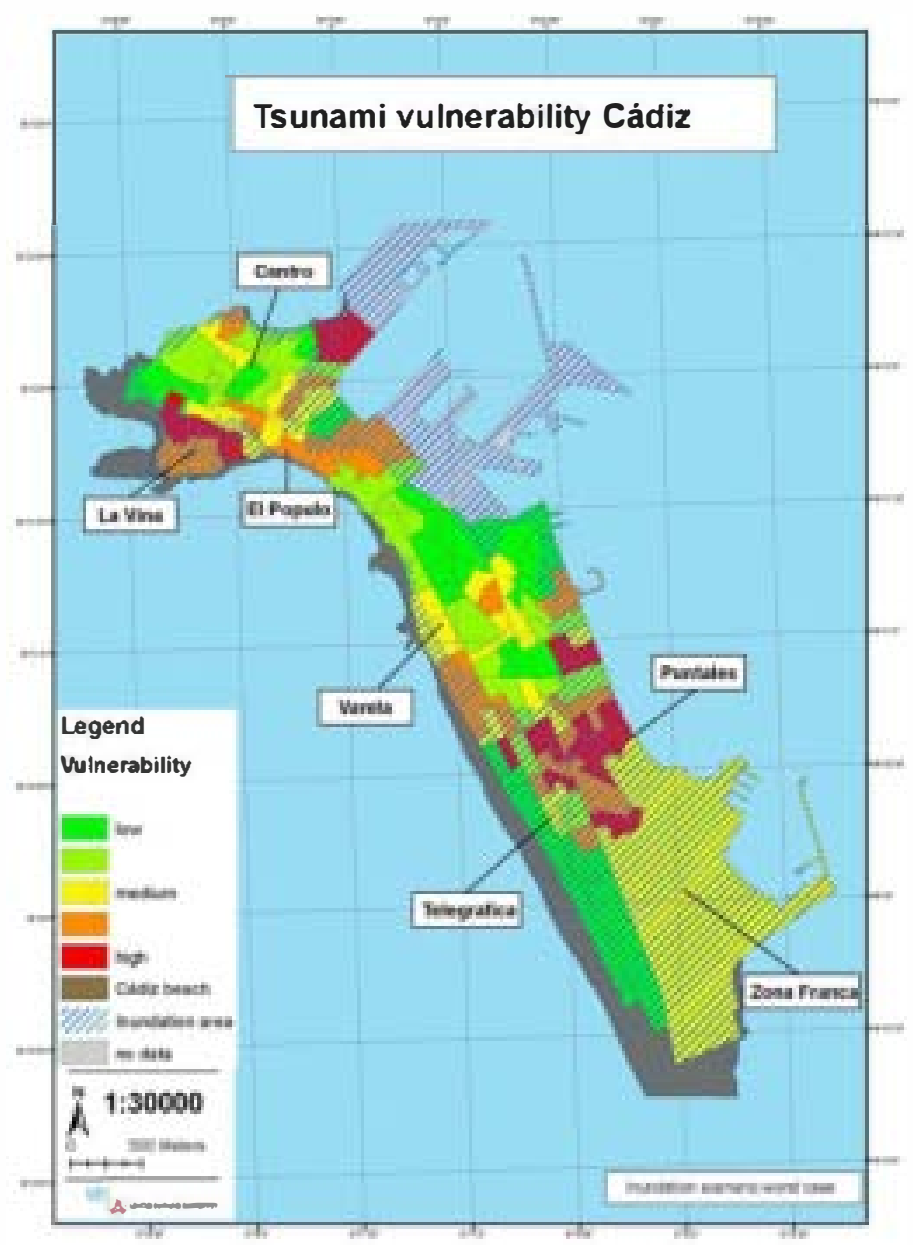

Fig. 7 Map of the population's vulnerability to the worst-case tsunami scenario (UCA 2009)

population may not be able to properly understand information on tsunami risks and waming in case of an acute hazardous event. All three components of vulnerability as well as the indicators that describe the components were equally weighted and summed up to one vulnerability index. The resulting tsunami vulnerability map of the population is presented in Fig. 7.

\subsection{Risk estimation}

In order to obtain the final risk value, the hazard and vulnerability information from the previous sections needs to be combined. Using the definition of risk as the product of hazard and vulnerability, a risk matrix of $5 \times 5$ classes, which relates the hazard and vulnerability, was developed (Table 5). Similar to the tsunami hazard assessment, the risk was categorised into five risk levels: very low, low, medium, high and very high. This table can serve for prioritising risk reduction as generally all very high and high-risk classes are considered unacceptable and require mitigation. The tsunami risk zonation maps in Fig. 8 
Table 5 Tsunami risk matrix

\begin{tabular}{llllll}
\hline Vulnerability & \multicolumn{1}{l}{ Hazard } & & & \\
\cline { 2 - 6 } & VL (1) & L (2) & M (3) & H (4) & VH (5) \\
\hline L (1) & VL $1 \times 1=1$ & L $1 \times 2=2$ & L $1 \times 3=3$ & L $1 \times 4=4$ & M $1 \times 5=5$ \\
$(2)$ & L $2 \times 1=2$ & L $2 \times 2=4$ & M $2 \times 3=6$ & M $2 \times 4=8$ & H $2 \times 5=1$ \\
M (3) & L $3 \times 1=3$ & M $3 \times 2=6$ & M $3 \times 3=9$ & H $3 \times 4=12$ & H $3 \times 5=15$ \\
(4) & L $4 \times 1=4$ & M $4 \times 2=8$ & H $4 \times 3=12$ & H $4 \times 4=16$ & VH $4 \times 5=2$ \\
H (5) & M $5 \times 1=5$ & H $5 \times 2=1$ & H $5 \times 3=15$ & VH $5 \times 4=2$ & VH $5 \times 5=25$ \\
\hline
\end{tabular}

Risk range: very low (=1), low (2-4), medium (5-9), high (10-16), very high (20-25)

are the result of the ranslation of these risk levels into a GIS environment. Overall, the key element in our risk assessment is the hazard component because it delineates the area affected by the inundation.

The tsunami risk maps calculated for the population located in the Cádiz city districts describe in relative terms the areas where the most fatalities can be expected due to the modelled tsunami scenario. These maps can be used as a preliminary tool for the identification of tsunami hot-spot areas or as risk indicator for planning and emergency response purposes. Particular attention should be paid to those areas that were assigned very high and high-risk levels. In these areas, a detailed quantitative study could be warranted.

Due to the strong influence of the choice of input parameters on the tsunami hazard level, also the tsunami risk for Cádiz exhibits this behaviour (Fig. 9). Assuming the maximum values for the water depth-velocity parameter, most of the districts of Cádiz come to lie in the very high-risk zone while there is no district in the very low-risk area. Clearly, the choice to model a worst-case scenario that is an aggregation of conservative scenarios from 5 seismic zones may have led to an overestimation of the risk. However, even for the minimum depth-velocity values, a significant number of districts are at very high and high risk. This seems to suggest that regardless of the assumptions made in this study a non-negligible tsunami risk to Cádiz exists.

\section{Discussion and conclusions}

A review of tsunami risk assessment approaches from different regions showed that the available methods for the estimation of tsunami risk are limited, since most studies have raditionally focused on tsunami hazard assessment. However, recent studies suggest a shift away from purely hazard-oriented approaches towards the consideration of vulnerability aspects and risk. This trend may have been riggered by decision makers' needs to be informed with updated information on the risk to certain areas.

Tsunami risk assessment can be performed using a probabilistic or a deterministic approach. The choice of the assessment approach depends on the data availability, purpose and the scale of analysis. For example, for preliminary national tsunami risk studies, the affected area can be simply determined by selecting a specific contour line. For sitespecific analysis, the use of numerical models supported by field studies may be necessary. Work in this direction is discussed in Birlemann (2007), where physical vulnerability indicators (households, housing blocks, city districts and sub-regions) are associated with different scales of analysis (from local to sub-national scale). Following the review of 

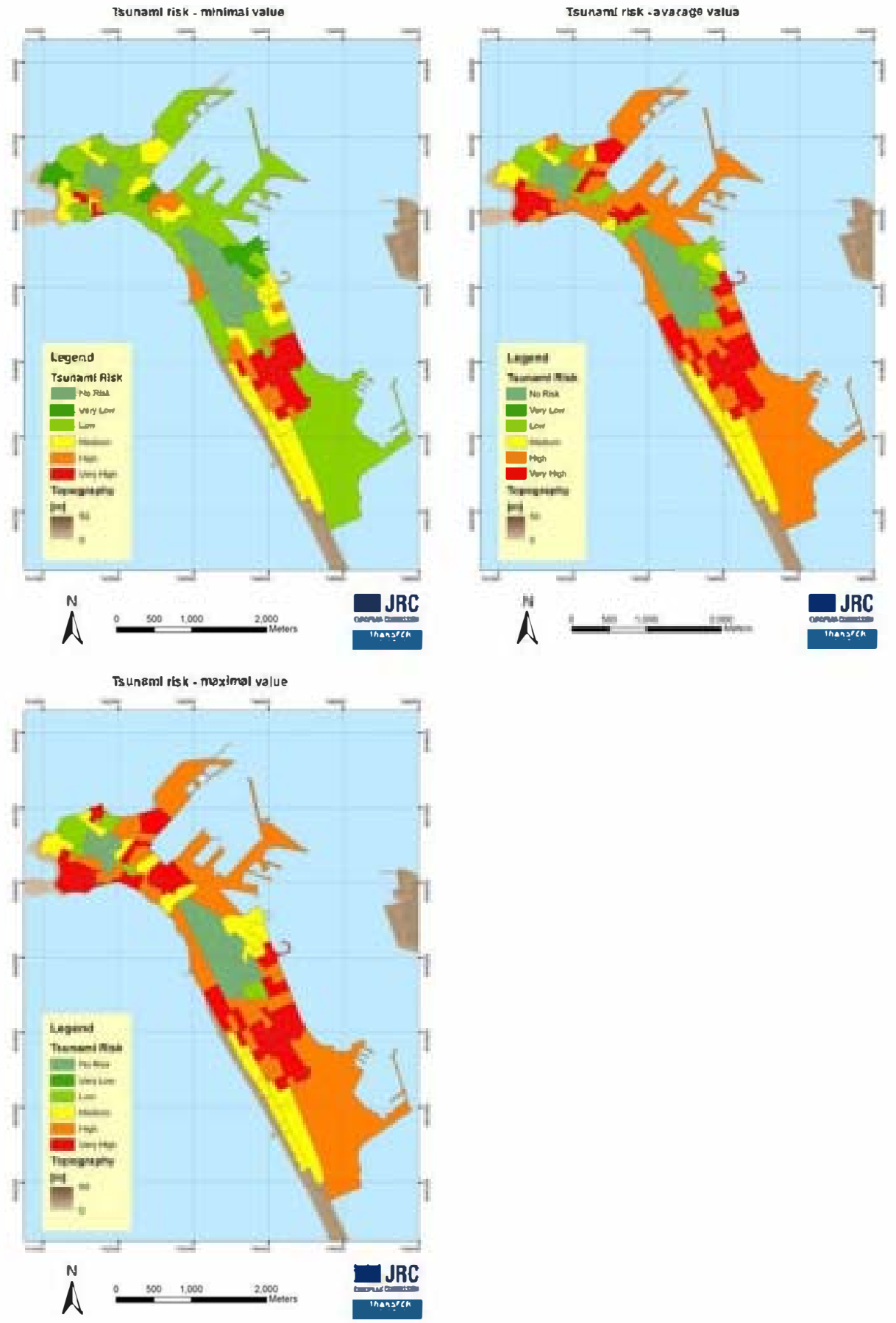

Fig. 8 Tsunami risk zonation maps for the minimum, average and maximum values of the tsunami risk to the population 


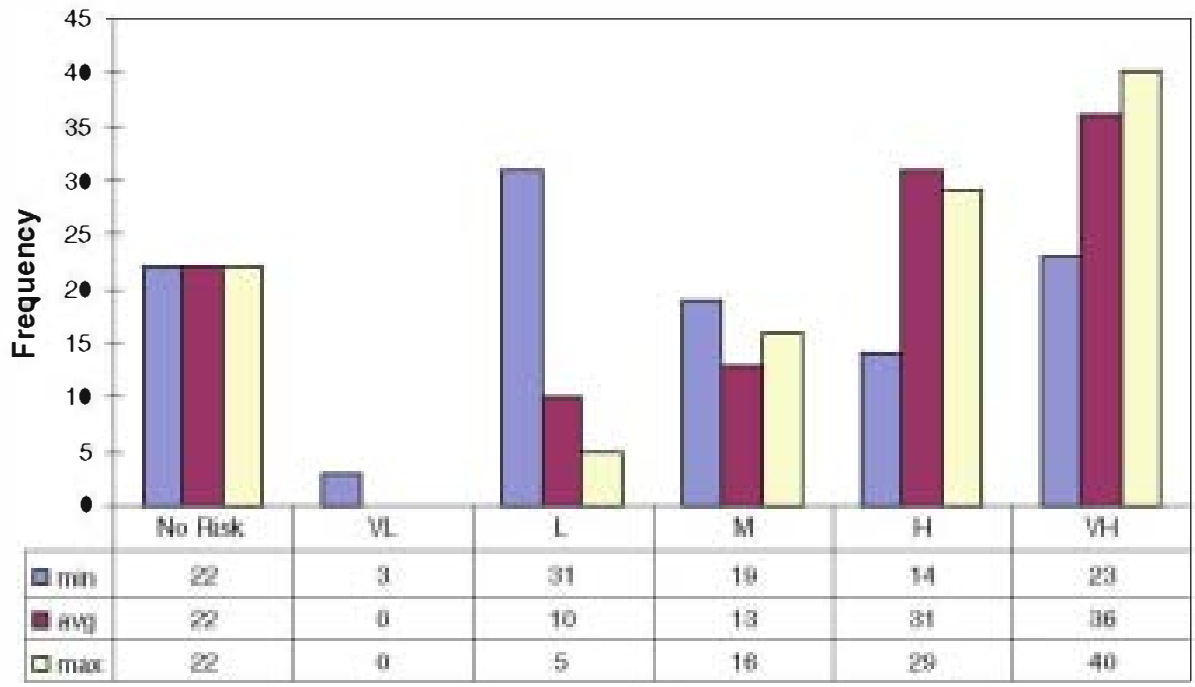

Fig. 9 Number of districts per risk level for the minimum, average and maximum values of the water depth-velocity product

several tsunami risk assessment methodologies in the literature, the following steps are proposed for the general process of tsunami risk assessment: scope definition and collection of historical data on past tsunamis, hazard characterisation, assessment of consequences, and risk estimation and evaluation.

Since the process of tsunami risk assessment is complex, it requires detailed lmowledge of the tsunami generation mechanisms, wave propagation, immdation and its possible consequences. Ideally, some measure of the likelihood of a given tsunami should also be available. The main difficulties are related to obtaining reliable input data for the risk assessment. Therefore, some simplifying assumptions may need to be made to perform the analysis. In case of Cádiz, the tsunami hazard was classified based on the water depth and velocity. The tsunami risk zonation maps were then developed from the hazard zonation maps and the vulnerability map.

The resultant hazard zonation maps created for minimum, maximum and average values of the depth velocity products showed a very high impact of the variability of the input parameters used. The characterisation of the hazard is therefore of particular importance for risk assessment. On the basis of the selected tsunami hazard parameters, scenarios for the analysis are defined, the affected area is delineated and the probability of the event is assigned. With respect to the choice to use the water depth and velocity for describing the hazard, it is legitimate to raise the question if these two parameters are sufficient for the characterisation of the tsunami hazard. Once could argue that other factors, such as the tsunami wave height, debris flow of the sediments, etc., should also be considered. Maybe future studies can shed some light on this issue and contribute towards a possible standardisation of the hazard parameters to be used as input for a tsunami risk assessment.

A high uncertainty is also associated with the estimation of the vulnerability, in particular with respect to the number of people exposed and the selection of relevant vulnerability indicators for the analysis. Although vulnerability was not discussed in detail in this work, this parameter seems to be the least developed and the most difficult to address. The used numerical models can introduce another source of uncertainty in the analysis. 
The errors are propagated, and consequently, the accuracy of the resultant risk maps is highly dependent on the accuracy of the models and input parameters used.

In spite of the high uncertainty in all stages of the risk-assessment process, the results can provide a valuable indication to civil-protection authorities and other decision makers where attention needs to be paid and where risk reduction measures may need to be implemented. Moreover, risk assessment is an important component for the development of effective tsunami early waming systems and for raising awareness of the hazard and its associated risks. Once recognised, they can be mainstreamed into emergency and strategic planning to create more hazard-resilient communities. This is also in accordance with the objectives and goals of the Hyogo Framework for Action (UNESCO-IOC 2009). The approach used in this study is straightforward and can be applied at an initial stage of the analysis. Once risk hot spots have been identified, more detailed analyses can follow to support the development of concrete prevention and mitigation measures.

Acknowledgments The authors acknowledge the European Union 6th Framework Programme Project TRANSFER in the frame of which this work was performed and funded.

\section{References}

AS/NZS 4360 (2004) Risk management. Standards Australia/Standards New Zealand

Australian Geomechanics Society (2000) Landslide risk management concepts and guidelines. Aust Geomech 35:1

Berryman K (2006) Review of tsunami hazard and risk in New Zealand. Institute of Geological and Nuclear Science, New Zealand

Birkmann J (ed) (206) Measuring vulnerability to natural hazards: towards disaster resilient socievies. United Nations University Press, New York

Birkmann J (207) Risk and vulnerability indicators at different scales: applicability, usefulness and policy implications. Environ Hazards 7:20-31

Birkmann J, von Teichman K, Welle T, González M, OlabarrietaM (201) The unperceived risk to Europe's coasts: tsunamis and the vunerability of Cadiz, Spain. Nat Hazards Earth Syst 10:2659-2675

Cox DC (1984) Importance of local contemporary reports of effects of bistorical tsunamis in tsunami risk analysis. Sci Tsunami Hazards 2(2):67-69

CPR (1999) Guidelines for quanitative risk assessment CPR 18E (purple book). CPR Committee for the Prevention of Disasters, The Hague

CSSC (205) The tsunami threat to Califomia: findings and recommendations on tsunami hazards and risks. Tsunami Safety Committee of the Seismic Safety Commission, CA

Curtis GD, Pelinovsli EN (1999) Evaluation of tsunami risk for mitigation and warning. Sci Tsunami Hazards 17(3): 187-192

Damaskinidou-Georgiadou A, Asce AM, Jolmson WJ (1987) Evaluation of tsunami risk at the southwest coast of the Iberian Peninsula, In: Magoon OT (ed) Coastal zone '87. Proceedings of the fifth symposium on coastal and ocean management, Seattle, May 26-29, 1987. American Society of Civil Engineers, pp 3346-3358

Defra (205) The threat posed by tsunami to the UK. Defra flood management. http://www.defra.gov.uk/ environment/flooding/documents/risk/tsunami 5.pdf. Accessed 6 July 21

Granger K, Jones T, Leiba M, Scott G (1999) Community risk in Cairns: a mulii-hazard risk assessment. Australian Geological Survey Organization, Canberra

Hébert H, Schindelé F, Heinrich $\mathbf{P}(201)$ Tsunami risk assessment in the Marquesas Islands (French Polynesia) through numerical modelling of generic far-field events. Nat Hazards Earth Syst 1:233-242

ISO 31000:2009 Risk management: principles and guidelines. International Organization for Standardizaion, Geneva, Switzerland

Jelínek R, Krausmann E (2008) Approaches to tsunami risk assessment. EUR 23573 EN. European Communities, OPOCE, Luxembourg

Jonkman SN, Vrijling JK, Vrouwenvelder ACWM (2008) Methods for the estrmation of loss of life due to floods: a literature review and a proposal for a new method. Nat Hazards 46(3):353-389 
Kulikov EA, Rabinovich AB, Thomson RE (2005) Estimation of tsunami risk for the coasts of Peru and northern Chile. Nat Hazards 35:185-209

Lee YK (1979) Tsunami risk analysis, In: Hwang LS, Lee YK (eds) Tsunamis: proceedings of the national science foundation workshop, May 1979, Tewa Tech., Pasadena, pp 254-271

Legg MR, Borrero J, Synolakis CE (203) Evaluation of tsunami risk to southern Califomia coastal cities. NEHRP professional fellowship report. Earthquake Engineering Research Institute (EERI), CA

Lima VV, Miranda JM, Baptista MA, Catalao J, González M, Otero L, Olabarrieta M, Álvarez-Gómez JA, Carreño E (210) Impact of a 1755-like tsunami in Huelva, Spain. Nat Hazards Earth Sys 10:139-148

Middelmann MH (ed) (207) Natural hazards in Auswalia. Iden ufying risk analysis requirements. Geoscience Australia, Canberra

Nadim F, Glade T (2006) On tsunami risk assessment for the west coast of Thailand. In: Nadim F et al (eds) ECI conference on geohazards. Lillehammer, Norway, pp 1-13

Nakamura S (1978) On statistical tsumami risk of the Philippines. South East Asian Stud 15(4):581-590

NEAREST (Integrated observations from near shore sources of tsunamis: toward an early waming system) (2010). http://nearest.bo.ismar.cnr.it. Accessed 6 July 210

Olabarrieta M, Medina R, González M, Otero L (210) C3: a finite volume-finite difference hybrid model for tsumami propagation and nu-up. Accepted for publication in computers and geosciences

Papadopoulos GA, Dennentzopoulos TH (1998) A tsunami risk management pilot study in Heraklion, Crete. Nat Hazards 18:91-118

Papathoma M, Dominey-Howes (2003) Tsunami vulnerability assessment and its implications for coastal hazard analysis and disaster management planning, Gulf of Corinth, Greece. Nat Hazards Earth Syst 3:733-747

Papathoma M, Dominey-Howes D, Zong Y, Smith (2003) Assessing tsunami vulnerability, an example from Herakleio, Crete. Nat Hazards Earth Syst 3:377-389

Pararas-Carayannis G (1988) Risk assessment of tsumami hazard. In: El-Sabah MI, Murty TS (eds) Natural and man-made hazards. D. Riedel, USA, pp 183-191

Post J, Wegscheider S, Mück M, Zosseder K, Kiefl R, Steinmetz T, Strunz G (2009) Assessment of human immediate response capability related to tsunami threats in Indonesia at a sub-national scale. Nat Hazards Earth Syst 9:1075-1086

Qinghai Z, Adams WM (1988) Tsunami risk analysis for China. Nat Hazards 1:181-185

Rascon OA, Villarreal AG (1975) On a stochastic model to estimate tsunami risk. J Hydraul Res 13(4):383-403

Rofi A, Doocy S (206) Tsunami mortality and displacement in Aceh province, Indonesia. Disasters $30(3): 34-350$

Rynn J, Davidson J (1999) Contemporary assessment of tsunami risk and implication for early warnings for Australia and its island territories. Sci Tsumami Hazards 17(2):107-125

SAFER (Seismic Early Warning for Europe) (2010) http://www.saferproject.net. Accessed 6 July 2010

SCHEMA (Scenarios for Hazard-induce Emergencies Management) (2010) http://schemaproject.net. Accessed 6 July 2010

SEAHELLARC (Seismic Risk Assessment and Mitigation Scenarios in the Western Hellenic Arc) (2010) http://www.seahellarc.gr. Accessed 6 July 2010

Symões JZ, Afilhado A, Victor LM (1992) Assessing the tsumami risk using insumental and historical records. Sci Tsumami Hazards 10(1):3-7

Synolakis CE, McCarthy D, Titov VV, Borrero J (1998) Evaluating the tsunami risk in California. In: Califomia and the world ocean ' 97 , ASCE, San Diego, pp 1225-1236

Thywissen K (206) Core terminology of disaster reduction: a comparative glossary. In: Birkmann J (ed) Measuring vulnerability to natural hazards. UNU Press, Tokyo, pp 448-496

Tini S, Amigliato A, Tonini R, Maramai A, Graziani L (2005) Assessing the hazard related to tsumamis of tectonic origin: a hybrid statical-detenninis method applied to southern Italy coasts. J Earthq Tech 42(4):189-201

Tini S, Tonini R, Pontrelli P, Pagnoni G, Santoro L (2018) Tsumami risk assessment in the Messina straits, Italy, with application to the urban area of Messina. Geophys Res Abst 10:EGU200-A-0845

TRANSFER (Tsunami Risk and Strategies for the European Region) (210) http://www. wansferproject.eu. Accessed 6 July 2010

UCA (209) Scenario flooding and risk maps, probabilistic risk maps for Cádiz city and Huelva community. Risk reduction measures for Cádiz, deliverable D8.2 of the 6th European framework programme project TRANSFER. http://www wansferproject.eu/. Accesse 16 Mar 211

UC-IGN (209) Tsumami inumation maps along the south west Spanish coast, deliverable $\mathbf{2} .1$ of the 6th European framework programme project TRANSFER. http://www.ransferproject.eu/. Accessed 16 Mar 2011 
UNESCO-IOC (2009) Hazard awareness and risk mitigation in integrate coastal management (ICAM). Intergovernmental Oceanographic Commission. IOC manuals and guides, vo1 5•, ICAM Dossier No. 5 , UNESCO, Paris

Wisner B, Blaikie P, Cannon T, Davis I (2004) At risk: natural hazards, people's vulnerability and disasters, 2nd edn. Routledge, London

Zahibo N, Pelinovsky EN (2001) Evaluation of tsunami risk in the Lesser Antilles. Nat Hazards Earth Syst 1:221-231

Zitellini N, Gràcia E, Matias L, Terrinha P, Abreu MA, De Alteriis G, Henriet JP, Dañobeitia J, Masson DG, Mulder T, Ramella R, Somoza L, Diez S (2009) The quest for the Africa-Eurasia plate boundary west of the Strait of Gibraltar. Earth Planet Sci Lett 28 (1-4):13-5 